$\mathrm{K}$

\title{
MORALNOŚĆ PUBLICZNA JAKO PRZESŁANKA OGRANICZANIA WOLNOŚCI ZGROMADZEŃ
}

\section{Streszczenie}

Wolność zgromadzeń może podlegać ograniczeniom także z uwagi na konieczność ochrony moralności publicznej. Moralność publiczna stanowi bowiem przesłankę dopuszczalności ograniczeń tej wolności zarówno na gruncie prawa międzynarodowego, jak i prawa krajowego. Celem badawczym niniejszego opracowania jest w pierwszej kolejności ukazanie moralności publicznej jako przesłanki uzasadniającej ograniczenie wolności zgromadzeń w ujęciu unormowań międzynarodowych oraz regulacji konstytucyjnej, a następnie przeanalizowanie szczegółowych ustawowych przesłanek ingerencji w wolność zgromadzeń wchodzących w zakres moralności publicznej. Zgodnie z postanowieniami ratyfikowanych umów międzynarodowych oraz przepisami Konstytucji Rzeczypospolitej Polskiej, do ograniczenia omawianej wolności konieczne jest obowiązywanie przewidujących to przepisów. Niektóre obecnie obowiązujące, polskie regulacje ustawowe, już określają przesłanki stanowiące podstawę ograniczenia wolności zgromadzeń z uwagi na ochronę wartości mieszczących się w moralności publicznej. Zasadne są jednak zmiany ustawowe umożliwiające $\mathrm{w}$ większym zakresie stosowanie ograniczeń wolności zgromadzeń z uwagi na ochronę moralności publicznej.

Słowa kluczowe: moralność publiczna; wolność zgromadzeń; prawo o zgromadzeniach; ograniczenia wolności; wolność sumienia i religii

$* * * * *$

* Dr hab., Katedra Publicznego Prawa Gospodarczego, Wydział Prawa, Prawa Kanonicznego i Administracji, Katolicki Uniwersytet Lubelski Jana Pawła II, Al. Racławickie 14, 20-950 Lublin, e-mail: zacharczuk@kul.pl. ORCID: 0000-0002-2285-8193. 


\section{WSTEP}

Wolność zgromadzeń stanowi niewątpliwie fundament dla funkcjonowania zarówno człowieka jako jednostki społecznej, jak i demokratycznego państwa prawnego jako dobra wspólnego wszystkich obywateli. Niemniej jednak, jak każda wolność, tak i wolność zgromadzeń może podlegać ograniczeniom także z uwagi na potrzebę ochrony moralności publicznej. Moralność publiczna stanowi bowiem przesłankę dopuszczalności ograniczeń tej wolności zarówno na gruncie prawa międzynarodowego, jak i prawa krajowego. Pomimo jednak prawnego uregulowania tej kwestii na poziomie międzynarodowym i krajowym oraz pomimo istotności tego zagadnienia, widoczny jest brak poważniejszej naukowej refleksji, w szczególności w zakresie wykorzystywania tej przesłanki ograniczania wolności zgromadzeń w ustawodawstwie. Z tego też względu celem badawczym niniejszego opracowania jest w pierwszej kolejności ukazanie moralności publicznej jako przesłanki ograniczania wolności zgromadzeń w ujęciu unormowań prawnomiędzynarodowych oraz regulacji konstytucyjnej, a następnie ukazanie szczegółowych ustawowych przesłanek ingerencji w wolność zgromadzeń wchodzących w zakres moralności publicznej. W związku z tak określonym celem sformułowano tezę, zgodnie z którą niektóre z tych ustawowych przesłanek mogą stanowić podstawę do ograniczenia wolności zgromadzeń z uwagi na ochronę wartości mieszczących się w moralności publicznej.

Konstrukcja opracowania i jej treść wynika z postawionego celu i tezy badawczej. W pierwszej części wskazana będzie moralność publiczna jako przesłanka dopuszczalności ograniczania prawa do zgromadzania się w ujęciu prawa międzynarodowego. W drugiej części ukazana zostanie moralność publiczna jako konstytucyjna przesłanka ograniczania wolności zgromadzeń. W trzeciej zaś części zaprezentowane będą szczegółowe przesłanki ingerencji w wolność zgromadzeń, które wchodzą w zakres konstytucyjnej wartości moralności publicznej. 


\section{MORALNOŚĆ PUBLICZNA JAKO PRZESŁANKA} DOPUSZCZALNOŚCI OGRANICZANIA PRAWA DO ZGROMADZANIA SIĘ W UJĘCIU PRAWA MIĘDZYNARODOWEGO

Kwestia zgromadzania się zajmuje ważne miejsce w regulacjach prawa międzynarodowego. Prawo do zgromadzania się należy do tych praw, które mają podstawowe znaczenie dla człowieka. Z tego też względu postanowienia odnoszące się do tego prawa znalazły się w wielu multilateralnych umowach międzynarodowych wchodzących w zakres międzynarodowego systemu ochrony praw człowieka. Rozwój tych postanowień nastąpił po II Wojnie Światowej. Już w uchwalonej w Paryżu przez Zgromadzenie Ogólne Organizacji Narodów Zjednoczonych w dniu 10 grudnia 1948 r. Powszechnej Deklaracji Praw Człowieka ${ }^{1}$ w art. 20 ust. 1 odnajdujemy gwarancje prawa do wolności pokojowego zgromadzania się. Choć Powszechna Deklaracja Praw Człowieka jako rezolucja Zgromadzenia Ogólnego nie ma formalnie wiążącego charakteru, to nie ulega jednak wątpliwości, że od momentu uchwalenia posiadała ona doniosłe znaczenie. Stała się bowiem punktem wyjścia przyjmowanych w okresie późniejszym wielu umów międzynarodowych, zarówno tych globalnych, jak i regionalnych ${ }^{2}$. Rzeczpospolita Polska jest stroną w szczególności kluczowych w tym zakresie dwóch umów międzynarodowych gwarantujących prawo do zgromadzania się - Międzynarodowego Paktu Praw Obywatelskich i Politycznych, wypracowanego w ramach funkcjonowania Organizacji Narodów Zjednoczonych i otwartego do podpisu w Nowym Jorku dnia 19 grudnia 1966 r. ${ }^{3}$, oraz Konwencji o ochronie praw człowieka i podstawowych wolności, sporządzonej w ramach funkcjonowania Rady Europy w Rzymie dnia 4 listopada $1950 \mathrm{r}^{4}$

Zgodnie z art. 21 MPPOP uznaje się prawo do spokojnego zgromadzania się. W dalszej części tego przepisu jest mowa o tym, że na wykonywanie tego prawa nie mogą być nałożone ograniczenia inne niż ustalone

1 Powszechna Deklaracja Praw Człowieka, http://libr.sejm.gov.pl/tek01/txt/onz/1948.html [dostęp: 16.03.2020].

2 Symonides 2005, 270-271.

3 Dz. U. z 1977 r. Nr 38, poz. 16; dalej jako MPPOP lub Pakt.

4 Dz. U. z 1993 r. Nr 61, poz. 284; dalej jako EKPC lub Konwencja. 
zgodnie z ustawą i konieczne w demokratycznym społeczeństwie w interesie bezpieczeństwa państwowego lub publicznego, porządku publicznego bądź dla ochrony zdrowia lub moralności publicznej albo praw i wolności innych osób.

Gwarantowane tym przepisem prawo dotyczy jedynie zgromadzania się pokojowego, tj. takiego, które przebiega bez użycia przemocy czy broni i nie stanowi rozruchów lub zamieszek. Oczywiście omawiane prawo obejmuje nie tylko organizowanie i przeprowadzanie zgromadzeń, lecz także możliwość uczestniczenia w zgromadzeniach. Jak na to zwrócono uwagę wyżej, art. 21 MPPOP zawiera też klauzulę limitacyjną dotyczącą dopuszczalności ograniczania prawa do zgromadzania się. Należy przy tym podkreślić, iż w większości artykułów MPPOP zawierających klauzule limitacyjne zawarta jest przesłanka konieczności zapisania ograniczenia w ustawie. Tak skonstruowany został m.in. art. 18, 19 i 22 MPPOP. W odróżnieniu od nich art. 21 MPPOP przewiduje, że wymagana jest zgodność ograniczenia z ustawą. Nie wyrażono zatem w Pakcie formalnego zobowiązania, aby jakakolwiek restrykcja w korzystaniu z wolności zgromadzeń uwzględniona była w obowiązujących regulacjach prawnych. Takie sformułowanie pozwala na szerszy zakres interwencji właściwych organów władzy. Ponadto, zgodnie z jedną z przesłanek dopuszczalności ograniczenia prawa do zgromadzania się, uprawnione będzie jedynie takie ograniczenie, które uznaje się za konieczne w społeczeństwie demokratycznym. Omawiany przepis przewiduje możliwość ograniczania prawa do zgromadzania się z przywołaniem konieczności m.in. ochrony moralności publicznej ${ }^{5}$.

Mimo że nie tylko w art. 21 MPPOP, lecz jeszcze w kilku innych artykułach tej umowy międzynarodowej jest mowa o moralności publicznej, to w treści Paktu nie wyjaśnia się tego pojęcia. Takiego wyjaśnienia nie sformułował też Komitet Praw Człowieka, który jednak przykładowo wskazał, iż moralność publiczna nie może stanowić generalnej podstawy do ograniczania prawa osób należących do wspólnoty LGBT (tj. lesbijek, gejów, osób biseksualnych i transpłciowych) do zgromadzania się. W uwagach końcowych sformułowanych do sprawozdania Federacji Rosyjskiej z dnia 28 października 2009 r. w pkt 27 lit. c Komitet Praw Człowieka

5 Gliszczyńska-Grabias, Wiśniewski 2012. 
wprost stwierdził, że państwo-strona ma obowiązek podjęcia wszelkich niezbędnych środków w celu zagwarantowania w praktyce wykonywania prawa do pokojowego zgromadzania się na rzecz społeczności LGBT'b.

W Europie znaczący rozwój gwarancji prawa do zgromadzania się nastąpił w związku z potwierdzeniem tego prawa w Europejskiej Konwencji Praw Człowieka, lecz realne znaczenie zawdzięcza ono przede wszystkim bogatemu orzecznictwu Europejskiego Trybunału Praw Człowieka ${ }^{7}$, w którym dynamicznie interpretowano art. 11 EKPC, a w pewnym zakresie także orzecznictwu Trybunału Sprawiedliwości ${ }^{8}$, ponieważ prawo do zgromadzania się dotyczy też Unii Europejskiej.

Zgodnie $\mathrm{z}$ art. 11 ust. 1 EKPC każdy ma prawo do swobodnego, pokojowego zgromadzania się oraz do swobodnego stowarzyszania się, włącznie z prawem tworzenia związków zawodowych i przystępowania do nich dla ochrony swoich interesów. W artykule tym zawarta jest m.in. gwarancja prawa do zgromadzania się stanowiącego ważną formę udziału w życiu publicznym społeczeństwa hołdującego demokratycznym wartościom. Swoboda zgromadzeń należy bowiem do ważnych podstaw demokratycznego społeczeństwa i głównych warunków jego rozwoju. Można wręcz stwierdzić, że sposób, w jaki prawo to jest zapewniane i praktycznie przestrzegane przez władze, jest pewnym wskaźnikiem stanu demokracji ${ }^{9}$.

W orzecznictwie ETPC wielokrotnie podkreślano, że jednym z celów prawa do zgromadzania się wyrażonego w art. 11 EKPC jest ochrona opinii oraz wolności ich wyrażania ${ }^{10}$. Przepis ten chroni jednostkę głównie przed arbitralną ingerencją władz publicznych, w pewnych okolicznościach jednak, podobnie jak w przypadku wielu innych praw, władze mają pozytywny obowiązek odpowiednich działań mających zapewnić skutecz-

6 Concluding observations of the Human Rights Committee, CCPR/C/RUS/CO/6, https://tbinternet.ohchr.org/_layouts/15/treatybodyexternal/Download.aspx?symbolno=CCPR\%2FC\%2FRUS\%2FCO\%2F6\&Lang=en [dostęp: 16.03.2020].

7 Dalej jako ETPC.

8 Dalej jako TS.

9 Nowicki 2017.

10 Zob. np. wyrok ETPC z dnia 26 kwietnia 1991 r., Ezelin przeciwko Francji, 11800/85, Lex; wyrok ETPC z dnia 24 lipca 2012 r., Fáber przeciwko Węgrom, 40721/08, Lex. 
ne korzystanie z tej wolności ${ }^{11}$. Art. 11 EKPC chroni też demonstrację, która może irytować lub obrażać osoby sprzeciwiające się ideom lub żądaniom, jakie usiłuje głosić. Jego gwarancje odnoszą się do wszystkich zgromadzeń z wyjątkiem tych, których organizatorzy i uczestnicy mają gwałtowne zamiary lub w inny sposób zaprzeczają podstawom społeczeństwa demokratycznego ${ }^{12}$. Trybunał strasburski podkreślił przy tym, że do cech demokracji należy możliwość rozwiązywania problemów państwa w drodze dialogu, bez uciekania się do przemocy. Dlatego zdaniem ETPC nie ma usprawiedliwienia dla stawiania przeszkód grupie politycznej tylko z tego powodu, że domaga się ona publicznej debaty na temat sytuacji części ludności kraju w celu znalezienia rozwiązań zadowalających wszystkich zainteresowanych. ETPC zwrócił też uwagę, że środki prewencyjne, które ograniczają wolność zgromadzeń, stosowane w innych sytuacjach niż podżeganie do przemocy lub próby obalenia demokracji, nie służą demokracji, bez względu na to, jak szokujące dla władz mogą być niektóre poglądy ${ }^{13}$. W innym wyroku ETPC wskazał, iż władza nie może zakazać zgromadzenia tylko dlatego, że w jej ocenie przekaz zgromadzenia jest „niesłuszny”, zwłaszcza gdy przedmiotem krytyki są władze uprawnione równocześnie do odmowy zgody na zgromadzenie. Ograniczenia prawa do zgromadzania się ze względu na treści, jakie chcą przekazać uczestnicy zgromadzenia - korzystający w ten sposób z wolności wypowiedzi politycznych albo o sprawach publicznie ważnych - są w szczególności najsurowiej oceniane przez ETPC jako naruszenia art. $11 \mathrm{EKPC}^{14}$.

W tradycji europejskiej na prawo jednostki do swobodnego, pokojowego zgromadzania się składają się następujące uprawnienia: 1) prawo do swobodnego zorganizowania zgromadzenia, 2) prawo do swobodnego udziału w zgromadzeniu, 3) prawo do swobodnego kierowania zgromadzeniem $^{15}$. Na gruncie Konwencji prawo do swobodnego zgromadzania się nie jest prawem absolutnym i podlega ograniczeniom w granicach

11 Nowicki 2017.

12 Wyrok ETPC z dnia 24 lipca 2012 r., Fáber przeciwko Węgrom, 40721/08, Lex.

13 Wyrok ETPC z dnia 2 października 2001 r., Stankov i Zjednoczona Macedońska Organizacja Ilinden przeciwko Bułgarii, 29221/95, Legalis.

14 Wyrok ETPC z dnia 12 czerwca 2014 r., Primov i inni przeciwko Rosji, 17391/06, https://hudoc.echr.coe.int/eng\#\{,,itemid":[,,001-144673”] $\}$ [dostęp: 17.03.2020].

15 Wróbel 2010. 
przewidzianych w jej art. 11 ust. 2. Zgodnie z tym przepisem wykonywanie wymienionych wyżej uprawnień szczegółowych nie może podlegać innym ograniczeniom niż te, które określa ustawa i które są konieczne w społeczeństwie demokratycznym z uwagi na interesy bezpieczeństwa państwowego lub publicznego, ochronę porządku i zapobieganie przestępstwu, ochronę zdrowia i moralności lub ochronę praw i wolności innych osób. Omawiany przepis nie stanowi przeszkody w nakładaniu zgodnych z prawem ograniczeń w korzystaniu z tych praw przez członków sił zbrojnych, policji lub administracji państwowej. Termin „ograniczenie” obejmuje w przypadku zgromadzeń zarówno działania je poprzedzające oraz podejmowane w ich trakcie, jak i sankcje karne po ich zakończeniu ${ }^{16}$.

$\mathrm{Z}$ treści art. 11 ust. 2 EKPC wynika, iż moralność jest jedną z kilku przesłanek uzasadniających ewentualne ograniczenia. Pomimo braku opatrzenia rzeczownika „moralność” przymiotnikiem „publiczna”, unormowanie to można utożsamiać z klauzulą generalną „moralności publicznej”, jako że klauzule ograniczające z natury swej powołują się na wartości i interesy zbiorowe, które tłumaczą owo ograniczanie. Moralność ma tu zatem charakter publiczny ${ }^{17}$. Ogólnikowe sformułowania konwencyjne wręcz „wymuszają" posiłkowanie się orzecznictwem ETPC podczas stosowania omawianego przepisu. Natomiast obecność generalnych klauzul wiąże się z powstaniem tzw. „marginesu oceny”. Jest to ukształtowana przez praktykę orzeczniczą koncepcja rozumienia klauzul ograniczających wolność jednostki w ten sposób, że ostateczną odpowiedzialność za ich treść pozostawia się stronom Konwencji. Margines oceny dotyczy zatem implementacji i interpretacji przepisów tej umowy międzynarodowej. Jest to więc bardziej reguła uzasadniania niż interpretacji umożliwiająca ETPC okazanie poszanowania dla celów, które państwo chce osiągnąć. Stosowanie marginesu oceny nie znajduje podstawy w żadnym przepisie Konwencji (chyba że za taką podstawę uzna się sam fakt użycia w Konwencji sformułowań nieostrych, w stosowanie których wpisany jest luz decyzyjny), jest jednak praktykowane już od początku jej obowiązywania. Na straży prawa w kontekście uzasadnionego ograniczania go stoi przy tym zasada proporcjonalności. Ograniczenie praw musi być nie tylko przewidziane przez ustawę,

16 Nowicki 2017.

17 Kalisz 2013, 203. 
lecz także „konieczne w społeczeństwie demokratycznym”"18. ETPC wskazał, że ochrona opinii oraz wolność ich wyrażania jest jednym z celów prawa do zgromadzania się, o którym mowa w art. 11 EKPC. Dlatego też zasada proporcjonalności zobowiązuje do zachowania równowagi między wymaganiami związanymi z celami wymienionymi w art. 11 ust. 2 EKPC i wolnością wypowiedzi w postaci słów, gestów lub nawet milczenia przez osoby zebrane na ulicach lub w innych miejscach publicznych ${ }^{19}$. Z kolei TS podkreślił, iż z brzmienia art. 11 EKPC wynika, że wolność zgromadzeń może również być przedmiotem pewnych ograniczeń uzasadnionych względami interesu ogólnego, o ile odstępstwa te są przewidziane prawem, zainspirowane jednym celem bądź wieloma celami uzasadnionymi w świetle tych przepisów i niezbędne z punktu widzenia demokratycznego społeczeństwa, to jest usprawiedliwione nadrzędną potrzebą społeczną i w szczególności proporcjonalne do uzasadnionego celu, który realizują ${ }^{20}$.

Każde państwo ma pewną swobodę w konkretyzowaniu pojęcia konieczności uzasadniającej ograniczanie prawa do zgromadzania się. Określona przez państwo w drodze ustawy konieczna przesłanka następczo podlega przy tym ocenie ETPC. Sama koncepcja marginesu oceny związana jest natomiast z korespondującymi z powyższymi założeniami zasadami subsydiarności i sytuacyjności. Pierwsza z tych zasad oznacza, że ochrona międzynarodowa w zakresie praw człowieka ma na celu jedynie wspomaganie ochrony krajowej, a nie jej zastępowanie. Zasada ta wiąże się z kwestią „balansowania wartości” - w tym przypadku uniwersalną wartością, jaką jest prawo do zgromadzania się, a respektowaniem różnorodności kulturowej w państwach-stronach Konwencji. Z obowiązywaniem tej zasady wiąże się powściągliwość instytucji europejskich. Z kolei zasada sytuacyjności oznacza uwzględnianie warunków danego państwa-strony Konwencji oraz konkretnych okoliczności faktycznych. Najszerszy margines uznawany jest przez ETPC właśnie w sprawach dotyczących moralności, ponieważ nie istnieje ani uniwersalna, ani nawet jednolita dla Europy definicja czy koncepcja terminu „moralność”.

18 Tamże, 203-204.

19 Nowicki 2013.

20 Wyrok TS z dnia 12 czerwca 2003 r., Schmidberger przeciwko Austrii, C-112/00, Lex. 
Interpretacja klauzuli „moralności” pojawiła się w dość licznych orzeczeniach ETPC. Najwyraźniejszą ilustrację możliwości jej zastosowania stanowi jednak wyrok w sprawie Handyside, w którym ETPC stwierdził, iż na podstawie prawa wewnętrznego różnych państw nie sposób znaleźć jednolitej europejskiej koncepcji moralności. Poglądy prawne w tej dziedzinie różnią się w zależności od czasu i miejsca. Dzieje się tak szczególnie dziś, w dobie charakteryzującej się szybkimi zmianami opinii o moralności. Władze krajowe, ze względu na stały kontakt z tymi problemami na miejscu, potrafią lepiej od międzynarodowego sędziego ocenić wymagania dotyczące „ochrony moralności” i konieczność stosowania ograniczeń lub kar². W powołanym wyżej wyroku ETPC zaakcentował, że margines oceny przyznany jest władzom krajowym, będącym w bezpośrednim i ciągłym kontakcie z własnym społeczeństwem i mającym lepsze rozeznanie w przedmiocie różnorodnych, konkurujących w nim wartości. Dotyczy to zarówno krajowego ustawodawcy, jak i sądów, dokonujących wykładni i stosowania obowiązującego prawa - w tym współstosowania prawa krajowego oraz Konwencji. Z analizy orzecznictwa ETPC można wysnuć wniosek, że gdy istnieje konsensus dotyczący interpretacji poszczególnych pojęć konwencyjnych, wtedy nie można mówić o żadnym marginesie oceny. ETPC powołuje się na margines oceny wówczas, gdy w rozumieniu danego pojęcia można dostrzec rozbieżności (jak w przypadku „,moralności”). Sięganie po ten argument oznacza zazwyczaj, że sprawa kończy się orzeczeniem sprzyjającym państwu, które zostało pozwane. Zwolennicy takiego podejścia podkreślają, że stosowanie „marginesu oceny” ma na uwadze nie tylko różnorodność społeczeństw europejskich, lecz także dynamikę zmian aksjologicznych w nich zachodzących. Ich zdaniem koncepcja marginesu oceny potwierdza zatem dyskursywny charakter współczesnego prawa, który to dyskurs staje się jeszcze bardziej widoczny, gdy w grę wchodzi tak delikatna materia, jak akceptacja społeczna i równowaga pomiędzy integracją europejską a zachowaniem suwerenności i autonomii kulturowej poszczególnych państw. Z kolei przeciwnicy szerszego wykorzystywania „marginesu oceny” wysuwają argumenty podważające zasadność założeń stojących u podstaw tej koncepcji. W ich ocenie w praktyce

21 Wyrok ETPC z dnia 7 grudnia 1976 r., Handyside przeciwko Wielkiej Brytanii, 5493/72, https://hudoc.echr.coe.int/eng\#\{,itemid”:[,,001-57499”]\} [dostęp: 17.03.2020]. 
dochodzi wręcz do odmowy ochrony w szczególnie drażliwych sprawach moralnych, a margines oceny używany jest jako swoista wymówka służąca odsuwaniu przez ETPC konieczności zajęcia stanowiska. Przeciwnicy widzą w nim też zagrożenie dla podstawowego konwencyjnego celu ochrony praw człowieka, jakim jest jej ujednolicenie; ,margines oceny” w praktyce prowadzi - ich zdaniem - do subiektywnego i relatywistycznego stosowania Konwencji, a do wykorzystywania go dochodzi z reguły podczas konfrontacji mniejszości z większością, a więc w sytuacjach, w których ETPC powinien być szczególnie wrażliwy i wyczulony na ochronę formalnie gwarantowanych praw i nie uginać się pod presją większości ${ }^{22}$.

Charakterystyczne jest, że ETPC nie wykreował żadnej ogólnej definicji moralności, lecz wręcz podkreśla jej immanentny związek z lokalną aksjologią krajową i wartością elastyczności stosowania prawa. Uzasadnieniem takiego stanowiska ETPC jest fakt, iż to właśnie aksjologia budzi największe kontrowersje społeczne i dlatego konkretne okoliczności danego przypadku powinny być badane przez sąd krajowy. ETPC uznaje więc przysługujący ustawodawcom i sądom krajowym „margines oceny” i unika poszerzania swej jurysdykcji na owe delikatne materie, skupiając się na kontroli zgodności ewentualnie wprowadzonych ograniczeń z zasadą proporcjonalności ${ }^{23}$.

Mimo że moralność na gruncie prawa międzynarodowego stanowi przesłankę uzasadniającą ograniczanie prawa do zgromadzania się, to jednak, aby nastąpiło faktyczne jego ograniczenie, konieczne jest uregulowanie tej kwestii dodatkowo w prawie krajowym uwzględniającym uwarunkowania prawa międzynarodowego.

\section{MORALNOŚĆ PUBLICZNA JAKO KONSTYTUCYJNA PRZESŁANKA OGRANICZANIA WOLNOŚCI ZGROMADZEŃ}

Polski prawodawca konstytucyjny, uwzględniając znaczenie pokojowych zgromadzeń, wprowadził poprzez art. 57 Konstytucji Rzeczypo-

22 Kalisz 2013, 204-206.

23 Tamże, 209. 
spolitej Polskiej z dnia 2 kwietnia 1997 r. ${ }^{24}$ ochronę konstytucyjną tych zgromadzeń. Zgodnie z tym przepisem każdemu zapewnia się wolność organizowania pokojowych zgromadzeń i uczestniczenia w nich. Co niezwykle istotne, w omawianym przepisie jest mowa nie tyle o przysługującym każdemu prawie do zgromadzania się, ale o wolności zgromadzeń. Jest to ważne rozróżnienie. Jeśli bowiem mamy do czynienia z wolnością, to znaczy że państwo jej nie kreuje, a ma jedynie zabezpieczyć jej realizację ${ }^{25}$. Oznacza to, że realizacja wolności zgromadzeń zależy od swobodnej decyzji i aktywności zainteresowanych. Prawo wyznacza w tym przypadku sferę wolną od ingerencji władzy publicznej. Podstawowy zaś obowiązek władzy publicznej polega na zakazie nieuzasadnionej ingerencji w określoną w Konstytucji sferę aktywności jednostek ${ }^{26}$.

Ochrona konstytucyjna zgromadzeń wynika z tego, iż - jak podkreślił Trybunał Konstytucyjny - zgromadzenia posiadają szczególnie ważne znaczenie dla komunikacji międzyludzkiej, zarówno w sferze publicznej, jak i prywatnej. Są też formą uczestnictwa w debacie publicznej, a w konsekwencji - również w sprawowaniu władzy w demokratycznym społeczeństwie. Dlatego też celem wolności zgromadzeń jest nie tylko zapewnienie autonomii i samorealizacji jednostki, lecz także ochrona procesów komunikacji społecznej niezbędnych dla funkcjonowania demokratycznego społeczeństwa. U jej podstaw znajduje się zatem nie tylko interes poszczególnych jednostek, ale również interes ogólnospołeczny. Wolność zgromadzeń stanowi konieczny element demokracji i warunkuje korzystanie $\mathrm{z}$ innych wolności i praw człowieka związanych ze sferą życia publicznego ${ }^{27}$. Wolność zgromadzeń chroni leżącą w interesie publicznym możliwość kształtowania i wyrażania opinii (pozytywnych, krytycznych, protestów itp.) różnych grup społecznych na interesujące je sprawy i w ten sposób zapewnia im wpływ na demokratyczny proces podejmowania decyzji ${ }^{28}$.

Z wolności tej może korzystać każdy, a zatem zarówno osoby fizyczne (obywatele polscy, cudzoziemcy, bezpaństwowcy), jak i osoby prawne

24 Dz. U. Nr 78, poz. 483 z późn. zm.

25 Skrzydło 2013.

26 Sokolewicz, Wojtyczek 2016.

27 Wyrok TK z dnia 28 czerwca 2000 r., K 34/99, OTK 2000/5/142.

28 Banaszak 2012. 
(np. stowarzyszenia, partie polityczne). Przepis art. 57 Konstytucji wymienia dwa uprawnienia składające się na przedmiotową wolność. Dotyczą one organizowania zgromadzeń oraz uczestniczenia w nich ${ }^{29}$.

Wolność zgromadzeń nie jest absolutna, co potwierdza art. 57 zd. 2 Konstytucji. Przepis ten bowiem wprost przewiduje dopuszczalność ograniczeń tej wolności, formułując jedynie wymóg ustawowej formy ingerencji państwa $^{30}$. Jak podkreślił Naczelny Sąd Administracyjny, z przepisu tego nie można jednak wyciągać wniosku, że ustawodawca może w dowolny sposób decydować o treści i zakresie ograniczeń wolności zgromadzeńn ${ }^{31}$. W związku z tym, iż w art. 57 zd. 2 Konstytucji nie zawarto żadnych klauzul ograniczających, to zastosowanie w tym zakresie ma art. 31 ust. 3 Konstytucji. Zgodnie $\mathrm{z}$ tym przepisem ograniczenia $\mathrm{w}$ zakresie korzystania z konstytucyjnych wolności i praw mogą być ustanawiane tylko w ustawie i tylko wtedy, gdy są konieczne w demokratycznym państwie dla jego bezpieczeństwa lub porządku publicznego bądź dla ochrony środowiska, zdrowia i moralności publicznej albo wolności i praw innych osób. Ograniczenia te nie mogą naruszać istoty wolności i praw.

W doktrynie prawa konstytucyjnego podkreśla się, iż istotą art. 31 ust. 3 Konstytucji, konkretyzującego wynikającą z klauzuli generalnej państwa prawa zasadę proporcjonalności, jest określenie przesłanek koniecznych dla wprowadzenia ograniczeń praw i wolności ${ }^{32}$. Z ugruntowanego orzecznictwa TK wynika, iż przepis ten odnosi się do wszystkich konstytucyjnych wolności i praw, niezależnie od tego, czy przepisy szczegółowe odrębnie określają przesłanki ograniczenia danego prawa i wolności ${ }^{33}$. Uzasadnione jest zatem stanowisko, iż wartości wymienione w art. 31 ust. 3 Konstytucji mogą uzasadniać także ograniczenie wolności zgromadzeń. Trybunał Konstytucyjny wielokrotnie przy tym podkreślał, że ograniczenia wolności zgromadzeń, ustanawiane na podstawie art. 57 (zdanie drugie) Konstytucji, muszą spełniać wszystkie wymogi konstytucyjne, określone w art. 31 ust. 3 Konstytucji ${ }^{34}$. To zaś oznacza, iż do tego

29 Florczak-Wątor 2019, 197.

30 Tamże, 198.

31 Wyrok NSA z dnia 6 sierpnia 2010 r., I OSK 155/10, Lex.

32 Czarnek 2014, 239.

33 Wyrok TK z dnia 10 kwietnia 2002 r., K 26/00, OTK-A 2002/2/18.

34 Wyrok TK z dnia 28 czerwca 2000 r., K 34/99, OTK 2000/5/142. 
przepisu musi nawiązywać badanie dopuszczalności rozwiązań ustawowych wprowadzających ograniczenie wolności zgromadzeń. Każde ograniczenie należy zatem ocenić zarówno z punktu widzenia „konieczności w demokratycznym państwie", jak i w powiązaniu z jedną z przesłanek określonych w powołanym przepisie konstytucyjnym. Ostatecznie dopuszczalność ograniczenia wolności zgromadzeń uzależniona jest od tego, czy w danej sytuacji wprowadzone ograniczenie nie dotyka samej istoty omawianej wolności, uniemożliwiając przez to jej wykonywanie ${ }^{35}$.

Trybunał Konstytucyjny wielokrotnie wypowiadał się na temat oceny konieczności ograniczeń w odniesieniu do wolności zgromadzeń. W szczególności stwierdził, że wymóg „konieczności w demokratycznym państwie” oznacza obowiązek zachowania zasady proporcjonalności. Z zasady tej wynika nakaz: 1) stosowania środków, które umożliwiają skuteczną realizację zamierzonych celów; 2) stosowania środków niezbędnych, tzn. środków najmniej uciążliwych dla jednostki; 3) zachowania odpowiedniej proporcji między korzyścią, którą przynoszą zastosowane środki, a ciężarem nałożonym na jednostkę. To zaś oznacza, iż ocena proporcjonalności ograniczenia tej konkretnej wolności musi być prowadzona z uwzględnieniem surowych kryteriów jego niezbędności. Jest to podyktowane szczególnym znaczeniem wolności zgromadzeń zarówno w odniesieniu do jednostki, jak i w kontekście rozwoju demokratycznego społeczeństwa. Co więcej, wprowadzenie ograniczeń jest możliwe tylko w sytuacjach, w których istnieje szczególnie istotna potrzeba ochrony jednej z wartości wskazanych w art. 31 ust. 3 Konstytucji. Jako niezbędne nie mogą być traktowane takie ograniczenia wolności zgromadzeń, które prowadzą do zamrożenia debaty społecznej i wymuszonego milczenia o nieujawnionych zjawiskach ${ }^{36}$.

Ograniczenia wolności zgromadzeń nie mogą opierać się - jak słusznie zauważył NSA - na domniemanych zagrożeniach innych wartości prawem chronionych, ponieważ wyważenie wolności konstytucyjnej i domniemanego zagrożenia określonej wartości nie pozwala na przypisanie temu domniemaniu pierwszeństwa ${ }^{37}$. To z kolei oznacza, iż ograniczenia tej wol-

35 Wyrok TK z dnia 18 września 2014 r., K 44/12, OTK-A 2014/8/92.

36 Wyrok TK z dnia 10 lipca 2008 r., P 15/08, OTK-A 2008/6/105.

37 Wyrok NSA z dnia 5 stycznia 2011 r., I OSK 1907/10, Lex. 
ności nie mogą dotyczyć tylko naruszeń innych wartości, lecz także ich rzeczywistych zagrożeń.

Wskazać należy, iż wyliczenie z art. 31 ust. 3 Konstytucji ma charakter wyczerpujący, chociaż nie ulega wątpliwości, że sformułowanie „konieczne w demokratycznym państwie dla jego bezpieczeństwa lub porządku publicznego, bądź dla ochrony środowiska, zdrowia i moralności publicznej, albo wolności i praw innych osób" jest bardzo ogólne ${ }^{38}$. W wyliczeniu wartości uzasadniających ograniczenia wolności zgromadzeń, zawartym w omawianej klauzuli limitacyjnej, znajduje się m.in. moralność publicz$n^{39}$. Mimo że pojęcie „moralność publiczna” jest pojęciem konstytucyjnym, a przede wszystkim wartością ważną m.in. dla prawa administracyjnego, to w orzecznictwie TK i innych sądów nie podjęto próby ogólnego zdefiniowania tego pojęcia. Co więcej, TK odwoływał się do przesłanki moralności publicznej tylko w kilku wyrokach, zazwyczaj nie wyjaśniając szerzej jej treści ${ }^{40}$. Wszelkie próby wyjaśnienia tego pojęcia przez TK były zawsze mocno osadzone w konkretnym kontekście sytuacyjnym, a elementy moralności publicznej definiowano w zależności od instytucji prawnych, których była tłem ${ }^{41}$. To zaś potęguje sporność sformułowanych w tych orzeczeniach definicji omawianego pojęcia. Przykładowo w jednym ze swoich wyroków TK stwierdził, że na moralność publiczną składa się pewne zaufanie obywateli do państwa, a więc z jednej strony - do jego funkcjonariuszy, a z drugiej - do stanowionego przezeń prawa, które wiąże zarówno wszystkich obywateli bez względu na sprawowane przez nich funkcje, jak i samo państwo ${ }^{42}$. Z tej definicji wynika, iż według TK publicznie moralne jest więc posłuszeństwo państwu i zaufanie do jego organów, postawy zaś przeciwne nie są publicznie moralne ${ }^{43}$. W innym zaś

38 Czarnek 2014, 239.

39 W innych przepisach Konstytucji występuje również termin „moralność”, lecz bez przydawki „publiczna” - stanowi ona przesłankę wyłączenia jawności rozprawy (art. 45 ust. 2) i ograniczenia wolności uzewnętrzniania religii (art. 53 ust. 5), natomiast wyznawane przez obywatela ,zasady moralne” mogą uzasadniać zamianę obowiązku służby wojskowej na służbę zastępczą (art. 85 ust. 3).

40 Podkowik 2019, 25.

41 Kalisz 2013, 202.

42 Wyrok TK z dnia 6 lipca 1999 r., P 2/99, OTK 1999/5/103.

43 Zimmermann 2018, 564. 
wyroku, ogólnie rzecz ujmując, TK definiował moralność publiczną jako normy moralne uznane w społeczeństwie polskim i odnoszące się do stosunków międzyludzkich ${ }^{44}$.

W tym miejscu trzeba podkreślić, iż istnieje trudność w ustaleniu powszechnie akceptowalnej definicji terminu „moralność publiczna”. Co więcej, już samo wyodrębnienie kategorii moralności publicznej budzi poważne kontrowersyjne.

Przykładowo zdaniem J. Zimmermanna z moralności publicznej nie należy czynić aksjomatu prawa administracyjnego, choć nie jest ona dla tego prawa pozbawiona znaczenia. Prawo administracyjne, z założenia publiczne i chroniące przede wszystkim interes publiczny, nie może jednak ograniczać i wymagać, aby jednostka preferowała moralność publiczną w swoich zachowaniach. Jednostka powinna być bowiem posłuszna prawu, ale nie musi to dla niej oznaczać żadnego imperatywu wiążącego na płaszczyźnie moralnej ${ }^{45}$. Zreferowane stanowisko pokazuje, iż niektórzy przedstawiciele doktryny optują za powściągliwym stosowaniem moralności publicznej w odniesieniu do ustalania treści ograniczeń wolności konstytucyjnych, w tym wolności zgromadzeń. Niekiedy wręcz postuluje się całkowite zaniechanie odwoływania się do niej. Pojawia się bowiem obawa, że kryterium moralności publicznej może stanowić furtkę do narzucania społeczeństwu przez rządzącą większość jakichś wzorców doskonałości, co byłoby jednak niedopuszczalne w pluralistycznym społeczeństwie, opartym na neutralności światopoglądowej. Jest to w pewnym zakresie konsekwencją złożoności szerszego problemu zajmującego filozofów prawa od stuleci, dotyczącego relacji norm prawnych ustanawianych przez władzę publiczną do wartości, którym normy mają służyć i które powinny urzeczywistniać ${ }^{46}$.

Inni przedstawiciele doktryny podnoszą, że żaden system prawny nie jest i nie powinien być moralnie neutralny. Zasadność odwoływania się przez prawodawcę do kryterium moralności publicznej wynika z potrzeby obiektywizacji, przy czym konsekwencje zachowania ocenionego jako naruszające kryterium moralności nie mogą się ograniczać do wywołania

\footnotetext{
44 Wyrok TK z dnia 10 grudnia 2014 r., K 52/13, OTK-A 2014/11/118.

45 Zimmermann 2018, 564.

46 Podkowik 2019, 21.
} 
dyskomfortu pojedynczych obywateli. Taki skutek można ocenić jako naruszenie praw i wolności innych osób. Z tego też względu w przypadku kryterium moralności niezbędny jest szeroki skutek przynoszący negatywny efekt dla ogółu i powszechnie za taki uznawany. Powoduje to trudność ze stosowaniem tej przesłanki, ponieważ rozumienie i stosowanie ocen moralnych jest w społeczeństwie zróżnicowane, a także podlega zmianom. Stąd kryterium o tak niejednolitym charakterze stwarza problemy wynikające $\mathrm{z}$ aksjologicznej treści przesłanki moralności ${ }^{47}$. Niektórzy przedstawiciele doktryny utożsamiają moralność publiczną z dominującym w polskim społeczeństwie chrześcijańskim systemem wartości, inni przestrzegają przed ustalaniem treści zasad moralnych tylko na podstawie jednej dominującej tradycji filozoficznej lub religijnej, jeszcze inni opowiadają się za całkowitym wyeliminowaniem kryterium moralności publicznej w celu usunięcia gruntu dla dyskursu o przesłankach światopoglądowych.

Nie podejmując się ukazania nie tylko znacznego, lecz także niezwykle zróżnicowanego dorobku doktryny zarówno w zakresie rozumienia moralności publicznej, jak i samej moralności ${ }^{48}$, warto przytoczyć definicję tego pojęcia wypracowaną przez J. Podkowika. Według tego autora moralność publiczna, przeciwstawiana $\mathrm{z}$ reguły moralności prywatnej (indywidualnej), jest składową moralności ogólnej rozumianej jako nieskodyfikowany i niesformalizowany zbiór norm, wartości, idei lub przekonań odnoszących się do postępowania człowieka wobec innych i samego siebie, kwalifikujących dane postępowanie w kategorii postępowania dobrego lub złego. Moralność stanowi przeto zbiór złożony z niejednorodnych elementów. Może mieć aspekt pozytywny i negatywny. W pozytywnym znaczeniu wzorce moralne obejmują nakazy postępowania uznawanego za dobre i pożyteczne (cnoty moralne), z kolei w aspekcie negatywnym konkretyzują się w zakazach postępowania uznawanego za niepożądane i wywołujące społeczne szkody ${ }^{49}$. Ponadto w ocenie J. Podkowika moralność publiczną należy postrzegać jako minimum systemu aksjologicznego wspólnego wszystkim (w tym mniejszościom) tworzącym naród polityczny (minimum etyczne) $)^{50}$.

\footnotetext{
47 Szubiakowski 2017.

48 Zob. szerzej: Podkowik 2019, 23-24.

49 Tamże, 32-33.

50 Tamże, 35.
} 
Niemniej jednak zastrzega on, iż moralność publiczna, uzasadniająca ograniczenie w korzystaniu z wolności i praw, powinna obejmować tylko te normy, wartości, idee i przekonania odnoszące się do zachowań mieszczących się w konstytucyjnie chronionym zakresie wolności lub praw podmiotowych, które są objęte negatywnym aspektem moralności. Tak rozumiana moralność publiczna nie powinna obejmować natomiast pozytywnego aspektu moralności. Perfekcjonizm moralny jednostek powinien być kwestią ich sumienia i wolnego wyboru, nie zaś nakazu prawnego. W państwie demokratycznym, zasadzającym się na paradygmacie ochrony wolności jednostki, powinno to pozostawać poza sferą oddziaływania prawodawcy ${ }^{51}$.

Moralność publiczna powinna być postrzegana jako minimum etyczne powszechnie uznawane przez Polaków, ponieważ art. 31 ust. 1 Konstytucji dozwala na ograniczenia m.in. wolności zgromadzeń tylko w drodze (polskiej) ustawy i tylko wtedy, gdy są one konieczne w demokratycznym państwie dla moralności publicznej obejmującej swym zakresem ogólne standardy moralne obowiązujące w polskim społeczeństwie. Co więcej, ogólne standardy moralne społeczeństwa polskiego wynikają w dużej mierze z tradycji chrześcijańskiej. Tego ponad tysiącletniego chrześcijańskiego dziedzictwa Polski nie można zanegować. W preambule Konstytucji jest bowiem mowa o wdzięczności naszym przodkom m.in. za kulturę zakorzenioną w chrześcijańskim dziedzictwie Narodu. Te polskie standardy moralne są akceptowane nie tylko przez członków Kościoła Katolickiego, lecz także przez członków pozostałych kościołów chrześcijańskich. Co więcej, niektóre $\mathrm{z}$ tych wartości moralnych są uznawane również przez członków innych związków wyznaniowych, choćby mających tak jak chrześcijaństwo wspólne korzenie z judaizmem, a nawet przez część osób niewierzących. Z Komunikatu Centrum Badania Opinii Społecznej wynika, iż odsetek osób zaliczających się do raczej lub całkowicie niewierzących od lat pozostaje na stosunkowo niskim poziomie (od 3\% do 7\%) $)^{52}$. Co istotniejsze, z Komunikatu tego wynika, iż system wartości osób niewierzących tylko w niewielkim stopniu odbiega od tego,

51 Tamże, 37.

52 Centrum Badania Opinii Społecznej, Osoby niewierzące w Polsce - kim są oraz jakie uznają normy i wartości?. Komunikat z badań nr BS/134/2013, Warszawa, październik 2013, https://cbos.pl/SPISKOM.POL/2013/K_134_13.PDF, s. 3 [dostęp: 17.03.2020]. 
który wyznają respondenci określający się jako wierzący, zaś ich system norm jest już z założenia bardziej zrelatywizowany niż wierzących. Są oni zdecydowanie bardziej liberalni przede wszystkim w ocenie zachowań odnoszących się do różnych wymiarów moralności prywatnej, natomiast ich oceny zachowań z zakresu tzw. moralności publicznej w znacznie mniejszym zakresie różnią się od formułowanych przez osoby wierzące ${ }^{53}$. Oznacza to, iż jest możliwy - choć trudny do ustalenia - wspólny mianownik składający się z niektórych wartości wchodzących w zakres moralności publicznej, akceptowanych przez polskie społeczeństwo składające się zarówno z osób wierzących, jak i niewierzących (np. szacunek dla miejsc spoczynku zmarłych). Trzeba ponadto zauważyć, że w polskim społeczeństwie obowiązują odmienne - bardzo często wyższe - standardy moralne od tych obowiązujących w niektórych innych społeczeństwach Europy Zachodniej (np. holenderskim). Potwierdzeniem obaw dotyczących narzucania polskiemu społeczeństwu niższych standardów moralnych w związku z procesami integracyjnymi jest uchwała Sejmu Rzeczypospolitej Polskiej z dnia 11 kwietnia 2003 r. w sprawie suwerenności polskiego prawodawstwa w dziedzinie moralności i kultury ${ }^{54}$. Wprawdzie nie jest ona aktem powszechnie obowiązującym, niemniej jednak potwierdza w swej treści z jednej strony odmienność polskiego prawodawstwa w zakresie moralnego ładu życia społecznego, godności rodziny, małżeństwa i wychowania oraz ochrony życia, z drugiej zaś potrzebę zachowania tej odmienności $\mathrm{w}$ dobie integracji $\mathrm{z}$ innymi krajami europejskimi w ramach UE. Zgodnie ze stanowiskiem TK, posługiwanie się przez prawodawcę klauzulami odsyłającymi do funkcjonujących w danym społeczeństwie przekonań i ocen spełnia warunki prawidłowego tworzenia prawa w państwie prawnym ${ }^{55}$. To zaś oznacza, iż możliwe jest powoływanie się na przesłankę moralności publicznej przy ustawowym wprowadzaniu ograniczeń w zakresie korzystania z konstytucyjnej wolności zgromadzeń. Nie można się zgodzić ze stanowiskiem, że trudność w ustaleniu samego pojęcia moralności publicznej i dokładnego jego zakresu stanowi wystarczające uzasadnienie dla rezygnacji z powoływania się na tę przesłankę przy ocenie ingerencji

\footnotetext{
53 Tamże, 28.

54 M. P. Nr 19, poz. 290.

55 Wyrok TK z dnia 17 października 2000 r., SK 5/99, OTK 2000/7/254.
} 
W wolność zgromadzeń w procesie stanowienia prawa polskiego. Skoro ustrojodawca ją przewidział w Konstytucji, a także jest ona znana europejskiej kulturze prawnej, powinna być stosowana ${ }^{56}$. Moralność publiczna jako przesłanka, o której mowa w art. 31 ust. 3 Konstytucji, nie może być przy tym bezpośrednio stosowana wobec organizowanych zgromadzeń. Dopiero bowiem szczegółowe przesłanki wchodzące w zakres moralności publicznej określone przez ustawodawcę zwykłego mogą stanowić podstawę do ingerencji w wolność zgromadzeń w ramach stosowania prawa.

\section{SZCZEGÓŁOWE USTAWOWE PRZESŁANKI INGERENCJI W WOLNOŚĆ ZGROMADZEŃ WCHODZĄCE W ZAKRES KONSTYTUCYJNEJ WARTOŚCI MORALNOŚCI PUBLICZNEJ}

Z uwagi na brzmienie uregulowań konstytucyjnych, szczegółowych przesłanek ingerencji w wolność zgromadzeń należy szukać w regulującym tę kwestię ustawodawstwie, a więc - w pierwszej kolejności - w ustawie z dnia 24 lipca 2015 r. - Prawo o zgromadzeniach ${ }^{57}$. W przeciwieństwie do poprzednio obowiązującej ustawy z dnia 5 lipca 1990 r. - Prawo o zgromadzeniach ${ }^{58}$, w ogóle nie odnosi się ona do pojęcia moralności publicznej. Natomiast ustawa poprzednio obowiązująca czyniła to w art. 2, który stanowił, iż wolność zgromadzania się podlega ograniczeniom przewidzianym jedynie przez ustawy, niezbędnym do ochrony bezpieczeństwa państwowego lub porządku publicznego oraz ochrony zdrowia lub moralności publicznej albo praw i wolności innych osób, a także ochrony Pomników Zagłady w rozumieniu ustawy z dnia 7 maja 1999 r. o ochronie terenów byłych hitlerowskich obozów zagłady ${ }^{59}$. To, że obecnie obowiązujące Prawo o zgromadzeniach w ogóle nie odnosi się do pojęcia moralności publicznej nie oznacza, iż nie chroni ono tej wartości. W związku z tym, iż reguluje ono zasady i tryb organizowania, odbywania oraz rozwiązywania

56 Por. Podkowik 2019, 22.

57 Tekst jedn. Dz. U. z 2019 r. poz. 631; dalej jako u.p.z.

58 Tekst jedn. Dz. U. z 2013 r. poz. 397 z późn. zm.

59 Tekst jedn. Dz. U. z 2015 r. poz. 2120; dalej jako u.t.b.h.o.z. 
zgromadzeń $^{60}$, w tym normuje sprawy dopuszczalnego ograniczenia wolności zgromadzania się, istotne są określone w tym akcie normatywnym szczegółowe przesłanki ingerencji w omawianą wolność, które wchodzą w zakres konstytucyjnej wartości moralności publicznej.

W orzecznictwie sądowym jednolicie podnosi się to, iż skoro wolność zgromadzeń jest konstytucyjnie chroniona, to jakiekolwiek jej ograniczenia muszą być wprost w ustawie określone i wykluczone są wszelkie interpretacje rozszerzające czy wnioskowanie przez analogię ${ }^{61}$. Z uwagi na konstytucyjną wolność zgromadzeń przepisy Prawa o zgromadzeniach ustalają, iż podmiot, który chce zorganizować zgromadzenie, nie potrzebuje na to żadnego pozwolenia. Wystarczy samo zgłoszenie do właściwego organu gminy. Nie ma więc w polskim prawie, co do zasady, decyzji o zezwoleniu na zgromadzenie. Ustawodawca nie wymaga, aby organ administracji publicznej w formie jednostronnego rozstrzygnięcia zezwalał na odbycie się zgromadzenia ${ }^{62}$. Jednak ustawodawca wyposażył organ administracji publicznej w kompetencję do ingerencji w wolność zgromadzeń w drodze indywidualnego zakazu ${ }^{63}$. Zgodnie z art. 14 u.p.z., organ gminy wydaje decyzję o zakazie zgromadzenia przed planowaną datą jego odbycia, jeżeli:

1) jego cel narusza wolność pokojowego zgromadzania się, jest organizowane przez osobę nieposiadającą pełnej zdolności do czynności prawnych, uczestniczyłyby w nim osoby posiadające przy sobie broń, materiały wybuchowe, wyroby pirotechniczne lub inne niebezpieczne materiały lub narzędzia, lub jego odbycie narusza zasady organizowania zgromadzeń albo cel zgromadzenia, lub jego odbycie narusza przepisy karne,

2) jego odbycie może zagrażać życiu lub zdrowiu ludzi albo mieniu w znacznych rozmiarach,

${ }^{60}$ Zgodnie z art. 3 ust. 1 u.p.z., zgromadzeniem jest zgrupowanie osób na otwartej przestrzeni dostępnej dla nieokreślonych imiennie osób w określonym miejscu w celu odbycia wspólnych obrad lub w celu wspólnego wyrażenia stanowiska w sprawach publicznych.

${ }_{61}$ Postanowienie Sądu Apelacyjnego w Lublinie z dnia 12 października 2018 r., I ACz 1145/18, Lex; por. postanowienie Sądu Apelacyjnego w Warszawie z dnia 2 czerwca 2017 r., I Acz 889/17, Legalis.

62 Szustakiewicz 2012, 159-160.

63 Olejniczak-Szałowska 2020, 839. 
3) zgromadzenie ma się odbyć w miejscu i czasie, w których odbywają się zgromadzenia organizowane cyklicznie ${ }^{64}$.

Do ograniczenia wolności zgromadzeń może dojść nie tylko poprzez wydanie przed planowaną datą zgromadzenia decyzji o zakazie odbycia go (na podstawie art. 14 u.p.z.), lecz również poprzez wydanie w trakcie odbywającego się już zgromadzenia decyzji o rozwiązaniu go (na podstawie art. 20 ust. 3 u.p.z.). Zgodnie z art. 20 ust. 1 u.p.z. zgromadzenie może być rozwiązane przez przedstawiciela organu gminy, jeżeli jego przebieg zagraża życiu lub zdrowiu ludzi albo mieniu w znacznych rozmiarach, lub narusza przepisy tej ustawy albo przepisy karne, a przewodniczący zgromadzenia, uprzedzony przez przedstawiciela organu gminy o konieczności rozwiązania zgromadzenia, nie rozwiązuje go. Dodatkowo na gruncie Prawa o zgromadzeniach określona została osobna podstawa prawna do wydania decyzji o rozwiązaniu zgromadzenia zorganizowanego w ramach postępowania uproszczonego ${ }^{65}$ oraz decyzji o rozwiązaniu zgromadzenia spontanicznego $^{66}$. Z kolei do zgromadzeń organizowanych cyklicznie stosuje się odpowiednio m.in. przepisy art. 14 u.p.z. określającego warunki

64 Wilk 2019, 87-88.

65 Na podstawie art. 25 ust. 1 u.p.z. zgromadzenie zorganizowane w ramach postępowania uproszczonego może być rozwiązane przez przedstawiciela organu gminy, jeżeli jego przebieg zagraża życiu lub zdrowiu ludzi albo mieniu w znacznych rozmiarach, powoduje istotne zagrożenie bezpieczeństwa lub porządku ruchu drogowego na drogach publicznych, lub narusza przepisy tej ustawy albo przepisy karne, a organizator zgromadzenia, uprzedzony przez przedstawiciela organu gminy o konieczności rozwiązania zgromadzenia, nie rozwiązuje go.

${ }^{66}$ Zgodnie z art. 28 u.p.z. zgromadzenie spontaniczne może być rozwiązane przez funkcjonariusza kierującego działaniami Policji, jeżeli:

1) jego przebieg zagraża życiu lub zdrowiu ludzi albo mieniu w znacznych rozmiarach,

2) jego przebieg powoduje poważne zagrożenie bezpieczeństwa lub porządku publicznego,

3) powoduje ono istotne zagrożenie bezpieczeństwa lub porządku ruchu drogowego na drogach publicznych,

4) jego przebieg narusza przepisy tej ustawy albo przepisy karne,

5) zakłóca ono przebieg zgromadzenia zorganizowanego w trybie przepisów rozdziału 2 u.p.z., zgromadzenia zorganizowanego w trybie postępowania uproszczonego określonego w rozdziale 3 u.p.z. lub zgromadzenia cyklicznego zorganizowanego w trybie postępowania w sprawach zgromadzeń organizowanych cyklicznie określonego w rozdziale 3a u.p.z. 
wydania decyzji o zakazie zgromadzenia oraz art. 20 u.p.z., w którym sformułowano warunki wydania decyzji o rozwiązaniu zgromadzenia ${ }^{67}$.

Żadna ze wskazanych powyżej podstaw prawnych do wydania decyzji zarówno o zakazie zgromadzenia, jak i o rozwiązaniu zgromadzenia nie odnosi się expressis verbis do moralności publicznej. Chociaż jednak ani doktryna prawa, ani orzecznictwo sądowe nie analizują szerzej kwestii wpływu konstytucyjnej wartości moralności publicznej na określone w Prawie o zgromadzeniach przesłanki ingerencji w wolność zgromadzeń, to przyjąć należy, że moralność publiczna współokreśla zakres ograniczeń wolności zgromadzeń.

Sąd Apelacyjny w Krakowie w postanowieniu z dnia 10 lipca 2019 r. wydanym w ramach rozpatrywanej sprawy dotyczącej zakazu zgromadzenia wskazał, iż przy wykładni art. 14 pkt 1 i 2 u.p.z. należy uwzględnić to, że władze publiczne, w tym samorządowe, są zobowiązane do ochrony prawa do pokojowego gromadzenia się. Ciąży na nich również obowiązek powstrzymywania się przed stosowaniem nieuzasadnionych, bo niewynikających z rzeczywiście stwierdzonych faktów, ograniczeń tego prawa, czego formą jest zastosowanie sankcji zakazu organizacji zgromadzenia. Sięgnięcie po ten, wyjątkowy w zakresie zastosowania, instrument ograniczający gwarantowaną przez Konstytucję podstawową wolność, musi być uzasadnione przez istnienie rzeczywistych i ważnych powodów, które mieszczą się w katalogu zawartym w tym przepisie ${ }^{68}$. Z kolei Naczelny Sąd Administracyjny w wyroku z dnia 25 maja 2006 r. stwierdził, iż nie jest zadaniem organów administracji publicznej i sądów administracyjnych analizowanie haseł, idei i treści, które nie naruszają przepisów obowiązującego prawa, a którym służyć ma zgromadzenie, z punktu widzenia przekonań moralnych osób działających w imieniu organu administracji czy też sędziów zasiadających w składzie orzekającym sądu bądź też przekonań dowolnej części społeczeństwa. Dokonywanie takich zabiegów niweczyłoby konstytucyjną wolność zgromadzeń, a ponadto naruszałoby art. 8 pkt 2 (obowiązującej w chwili orzekania) ustawy z dnia 5 lipca 1990 r. - Prawo o zgromadzeniach. Zgodnie z powołanym przepisem organ gminy był bowiem upoważniony do zakazania zgromadzenia publicznego, jeżeli jego

${ }^{67}$ Zob. art. 26e u.p.z.

68 I ACz 977/19, Legalis. 
odbycie mogło zagrażać życiu lub zdrowiu ludzi albo mieniu w znacznych rozmiarach $^{69}$. Choć wyrok ten wydany został w oparciu o nieobowiązującą już ustawę, to przy obecnym stanie prawnym teza tam zamieszczona w dalszym ciągu wydaje się aktualna, ponieważ analizowana wówczas przez NSA przesłanka zastosowania sankcji zakazu organizacji zgromadzenia w istocie przeniesiona została do ustawy obecnie obowiązującej. Ponadto NSA słusznie w tym wyroku wskazał, iż wykładnia rozszerzająca art. 8 pkt 2 Prawa o zgromadzeniach, stanowiącego wyjątek od zasady wolności zgromadzeń, jest w demokratycznym państwie prawnym niedopuszczalna. Dlatego też przesłanką zakazania odbycia zgromadzenia nie może być okoliczność, że do zagrożenia dóbr określonych w tym przepisie może dojść w wyniku działań przeciwników zgromadzenia. Decyzja o zakazie zgromadzenia w oparciu o przesłankę zagrożenia życia lub zdrowia ludzi albo mienia w znacznych rozmiarach może być uzasadniona wyłącznie z odwołaniem się do działań organizatorów i uczestników zgromadzenia.

Podkreślić należy, iż moralność publiczna jako konstytucyjna przesłanka ograniczenia wolności zgromadzeń nie może być utożsamiana zakresowo tylko z moralnością w sferze seksualnej. Co więcej, nie ulega wątpliwości, że znaczna część norm, wartości, idei lub przekonań odnoszących się do postępowania człowieka wobec innych i wchodzących w zakres moralności publicznej objęta jest równocześnie regulacjami prawa polskiego, w tym znajduje odbicie w przepisach karnych, obejmujących także wykroczenia. $Z$ tego też względu również szczegółowe przesłanki wydania decyzji o zakazie zgromadzenia z art. 14 pkt 1 u.p.z. (w postaci celu lub przebiegu zgromadzenia jako naruszających przepisy karne) mogą mieścić się w konstytucyjnej przesłance moralności publicznej. Oczywiście nie wszystkie zachowania objęte negatywnym aspektem moralności naruszają przepisy karne. $Z$ tego też względu nie każdy godzący w moralność publiczną cel zgromadzenia lub fakt jego odbycia może być podstawą do wydania zakazu zgromadzenia na podstawie art. 14 pkt 1 u.p.z. Przykładowo, organizowanie zgromadzenia w celu manifestowania publicznie nagości na gruncie Prawa o zgromadzeniach będzie zakazane, ponieważ cel lub odbycie tego zgromadzenia naruszy art. 140 ustawy z dnia 20 maja 1971 r.

${ }^{69}$ Wyrok NSA z dnia 25 maja 2006 r., I OSK 329/06, Legalis. 
- Kodeks wykroczeń ${ }^{70}$, zamieszczony w jego Rozdziale XVI pt. „Wykroczenia przeciwko obyczajności publicznej” i dotyczący nieobyczajnego wybryku.

$\mathrm{W}$ tym miejscu warto wskazać, iż zgodnie z art. 2 u.p.z. przepisów tej ustawy nie stosuje się do zgromadzeń organizowanych przez organy władzy publicznej oraz odbywanych w ramach działalności kościołów i innych związków wyznaniowych ${ }^{71}$. A contrario, do wszystkich innych zgromadzeń zastosowanie znajdą przepisy Prawa o zgromadzeniach, o ile regulacje szczególne nie stanowią inaczej ${ }^{72}$. Jak podkreśla się w doktrynie, wyłączenie dotyczące zgromadzeń organizowanych przez organy władzy publicznej wynika z tego, iż zwoływanie zgromadzeń przez władze publiczne nie stanowi przejawu działalności obywatelskiej i nie jest realizacją wolności, o której mowa w art. 57 Konstytucji. Co więcej, zgromadzenie takie, pozostając, co do celu, organizacji i przebiegu, pod ścisłą kontrolą organu inicjującego, nie wymaga szczególnych zabezpieczeń proceduralnych ${ }^{73}$.

Zgromadzenia organizowane przez kościoły i inne związki wyznaniowe, do których nie stosuje się przepisów Prawa o zgromadzeniach, muszą odbywać się w „ramach działalności” tych podmiotów. Ramy te są wyznaczone przez dokumenty wewnętrzne kościołów i innych związków wyznaniowych (statuty, pisma teologiczne, zawierające poglądy dotyczące natury i cech charakterystycznych sfery sacrum oraz jej osobowych postaci itp. $)^{74}$. Do innych zgromadzeń organizowanych przez kościoły i inne związki wyznaniowe przepisy Prawa o zgromadzeniach znajdują zastosowanie.

Obecnie obowiązuje szereg odrębnych regulacji prawnych dotyczących poszczególnych kościołów i innych związków wyznaniowych. W odniesieniu do Kościoła Katolickiego, zgodnie z art. 15 ust. 2 ustawy z dnia 17 maja 1989 r. o stosunku Państwa do Kościoła Katolickiego w Rzeczypospolitej Polskiej ${ }^{75}$, publiczne sprawowanie kultu nie wymaga zawiadomienia, jeżeli odbywa się w kościołach, kaplicach, budynkach kościelnych i na gruntach kościelnych oraz w innych pomieszczeniach

70 Tekst jedn. Dz. U. z 2019 r. poz. 821 z późn. zm.

71 Rzetecka-Gil 2019.

72 Gajewski, Jakubowski 2017.

73 Sokolewicz, Wojtyczek 2016.

74 Suski 2014.

75 Tekst jedn. Dz. U. z 2019 r. poz. 1347; dalej jako u.s.P.K.K. 
służących katechizacji lub organizacjom kościelnym oraz w innych miejscach, z wyłączeniem dróg i placów publicznych oraz pomieszczeń użyteczności publicznej. Publiczne sprawowanie kultu na drogach, placach publicznych oraz $\mathrm{w}$ pomieszczeniach użyteczności publicznej podlega uzgodnieniu z właściwym organem sprawującym zarząd lub upoważnionym do dysponowania nimi. $Z$ kolei organizowanie procesji, pielgrzymek lub innych imprez o charakterze religijnym na drogach publicznych wymaga uzgodnienia, w zakresie bezpieczeństwa ruchu drogowego, z właściwymi organami administracji rządowej lub samorządowej ${ }^{76}$. Przepisy Prawa o zgromadzeniach stosuje się natomiast do organizacji kościelnych, gdy chodzi o zebrania na drogach i placach publicznych oraz w pomieszczeniach użyteczności publicznej ${ }^{77}$. Podobne przepisy można znaleźć w ustawach dotyczących innych związków wyznaniowych ${ }^{78}$.

Przepis art. 2 pkt 2 u.p.z. nie ogranicza ujętego w nim wyłączenia tylko do tych kościołów i innych związków wyznaniowych, których stosunki z państwem zostały uregulowane w odrębnym akcie normatywnym. Ma on również zastosowanie do związków wyznaniowych ujętych w rejestrze prowadzonym przez ministra właściwego do spraw wyznań religijnych, w stosunku do których stosuje się ustawę z dnia 17 maja 1989 r. o gwarancjach wolności sumienia i wyznania ${ }^{79}$. Na podstawie jej art. 19 ust. 2 pkt 2 kościoły i inne związki wyznaniowe, wypełniając funkcje religijne, mogą w szczególności określać doktrynę religijną, dogmaty i zasady wiary oraz liturgię, a także organizować i publicznie sprawować kult. Działalność tych kościołów i innych związków wyznaniowych nie może przy tym naruszać przepisów ogólnie obowiązujących ustaw chroniących bezpieczeństwo publiczne, porządek, zdrowie lub moralność publiczną, władzę rodzicielską albo podstawowe prawa i wolności innych osób. W zakres prawnych granic korzystania przez kościoły i inne związki wyznaniowe ze swobody działania wchodzi więc moralność publiczna. Z tego też względu, jeżeli wniosek o wpis do rejestru kościołów i innych związków wyzna-

76 Zob. art. 16 ust. 1 u.s.P.K.K.

77 Zob. art. 34 ust. 5 u.s.P.K.K.

78 Zob. np. art. 9 ustawy z dnia 30 czerwca 1995 r. o stosunku Państwa do Kościoła Polskokatolickiego w Rzeczypospolitej Polskiej (tekst jedn. Dz. U. z 2014 r. poz. 1599).

79 Tekst jedn. Dz. U. z 2017 r. poz. 1153; dalej jako u.g.w.s.w. 
niowych zawiera postanowienia pozostające w sprzeczności z przepisami ustaw chroniącymi moralność publiczną, organ rejestrowy wydaje decyzję o odmowie wpisu do rejestru ${ }^{80}$. W razie zaś stwierdzenia prawomocnym wyrokiem sądu, że działalność określonego kościoła lub innego związku wyznaniowego rażąco narusza prawo lub postanowienia statutu, organ rejestrowy wykreśla go z rejestru ${ }^{81}$. To z kolei oznacza, iż kwestia zgodności z moralnością publiczną będzie rozstrzygana przede wszystkim nie w odniesieniu do konkretnego zgromadzenia, lecz w odniesieniu do regulacji sytuacji prawnej związku wyznaniowego. Niemniej jednak jest możliwe wykreślenie związku wyznaniowego z rejestru w konsekwencji organizowania zgromadzeń naruszających moralność publiczną.

Odrębne zasady organizowania i odbywania zgromadzeń, wyłączające bądź modyfikujące stosowanie Prawa o zgromadzeniach, określają przepisy szczególne ${ }^{82}$. Z tego też względu ograniczenie sfery wolności zgromadzeń następuje nie tylko na podstawie przepisów Prawa o zgromadzeniach, lecz także na podstawie szeregu innych przepisów rangi ustawowej ${ }^{83}$. W pierwszej kolejności warto w tym miejscu wskazać powołaną już wyżej ustawę z dnia 7 maja 1999 r. o ochronie terenów byłych hitlerowskich obozów zagłady. Zdaniem TK szczególna ochrona tych terenów (Pomników Zagłady) wynika z konstytucyjnej wartości ochrony moralności publicznej, wymienionej również w art. 31 ust. 3 Konstytucji jako jedna z przesłanek ograniczenia korzystania z konstytucyjnych praw i wolności ${ }^{84}$. Zgodnie $\mathrm{z}$ art. 1 ust. 2 u.t.b.h.o.z. ochrona Pomników Zagłady polega na tworzeniu ich stref ochronnych oraz wprowadzeniu na ich obszarze i obszarze ich stref ochronnych szczególnych zasad m.in. odbywania zgromadzeń. Art. 7 ust. 1 u.t.b.h.o.z. stanowi, iż odbycie zgromadzenia na obszarze Pomnika Zagłady lub jego strefy ochronnej wymaga zgody wojewody, wydanej w drodze decyzji. Wojewoda odmawia zaś udzielenia tej zgody jeżeli:

1) cel lub odbycie zgromadzenia są niezgodne z przepisami ustawy o ochronie terenów byłych hitlerowskich obozów zagłady lub prze-

\footnotetext{
80 Zob. 33 ust. 3 u.g.w.s.w.

81 Zob. 36a ust. 2 u.g.w.s.w.

82 Gajewski, Jakubowski 2017.

83 Mamak 2014.

${ }^{84}$ Wyrok TK z dnia 10 listopada 2004 r., Kp 1/04, OTK-A 2004/10/105.
} 
pisami Prawa o zgromadzeniach albo naruszają przepisy ustaw karnych,

2) odbycie zgromadzenia może zagrażać życiu lub zdrowiu ludzi albo mieniu znacznej wartości,

3) cel lub odbycie zgromadzenia może naruszyć powagę lub charakter Pomnika Zagłady,

4) podmiot posiadający tytuł prawny do nieruchomości znajdującej się na obszarze Pomnika Zagłady lub jego strefy ochronnej nie wyraził zgody na odbycie zgromadzenia na tej nieruchomości.

Ponadto zgromadzenie może być rozwiązane przez przedstawiciela wojewody, jeżeli jego przebieg zagraża życiu lub zdrowiu ludzi albo mieniu znacznej wartości, narusza powagę lub charakter Pomnika Zagłady albo narusza przepisy ustawy o ochronie terenów byłych hitlerowskich obozów zagłady, Prawa o zgromadzeniach albo ustaw karnych, a przewodniczący, uprzedzony o konieczności rozwiązania zgromadzenia, wzbrania się to uczynić ${ }^{85}$.

Na podstawie art. 52 ust. 3 ustawy z dnia 20 lipca 2018 r. - Prawo o szkolnictwie wyższym i nauce ${ }^{86}$ rektor uczelni odmawia udzielenia zgody na zorganizowanie zgromadzenia w lokalu uczelni lub zakazuje zgromadzenia, jeżeli jego cel lub program naruszają przepisy prawa. Z kolei na podstawie art. 52 ust. 6 tej ustawy rektor albo jego przedstawiciel, po uprzedzeniu organizatorów, rozwiązuje zgromadzenie, jeżeli przebiega ono z naruszeniem przepisów prawa. Z przepisów tych wynika, iż przesłanką umożliwiającą odmowę udzielenia zgody na zorganizowanie zgromadzenia, wydanie zarówno zakazu zgromadzenia, jak i rozwiązania zgromadzenia, jest naruszenie przepisów prawa, a więc także tych chroniących moralność publiczną.

Przeprowadzone rozważania pozwalają na stwierdzenie, że obecnie zarówno Prawo o zgromadzeniach, jak i przepisy szczególne dotyczące niektórych zgromadzeń, mogą być podstawą do wprowadzenia ograniczeń wolności zgromadzeń z uwagi na potrzebę ochrony m.in. moralności publicznej. W związku z organizowaniem lub odbywaniem zgromadzeń wartość, jaką jest moralność publiczna, może być chroniona przede wszyst-

85 Zob. art. 7 ust. 4 i 9 u.t.b.h.o.z.

86 Tekst jedn. Dz. U. z 2020 r. poz. 85 z późn. zm. 
kim wówczas, gdy cel zgromadzenia lub jego odbycie, a także przebieg zgromadzenia, naruszają przepisy karne chroniące wartości wchodzące w zakres moralności publicznej. Na terenie uczelni natomiast wartość ta może być chroniona szerzej, a ingerencja w wolność zgromadzeń jest uzasadniona wówczas, gdy cel lub program zgromadzenia, lub jego przebieg naruszają przepisy prawa, w tym oczywiście zwłaszcza przepisy karne. Z kolei na obszarze Pomników Zagłady i ich stref ochronnych ograniczenia dotyczące zgromadzeń mogą być wprowadzone jeszcze szerzej. Są bowiem uzasadnione m.in. wówczas, gdy cel lub odbycie zgromadzenia może naruszyć powagę lub charakter Pomnika Zagłady oraz gdy podmiot posiadający tytuł prawny do nieruchomości znajdującej się na obszarze Pomnika Zagłady lub jego strefy ochronnej nie wyraził zgody na odbycie zgromadzenia na tej nieruchomości. Te ostatnie przesłanki umożliwiające wprowadzenie ograniczeń wobec zgromadzeń ukazują, iż ze względu na moralność publiczną mogą być przewidziane daleko idące ograniczenia wolności zgromadzeń. Dotyczy to jednak miejsc upamiętniających przede wszystkim ofiary Holokaustu. Pamiętać przy tym należy, iż w Polsce znajduje się także wiele innych miejsc upamiętniających walkę i męczeństwo, miejsc spoczynku osób zmarłych, które to miejsca zawsze powinny skłaniać do zadumy i szacunku. Niestety można mieć uzasadnione wątpliwości co do tego, czy tego typu miejsca zawsze są należycie chronione. Oczywiście podlegają one także ochronie prawnokarnej (np. na gruncie art. 261 ustawy z dnia 6 czerwca 1997 r. - Kodeks karny ${ }^{87}$, przewidującego odpowiedzialność karną za przestępstwo znieważenia pomnika lub innego miejsca publicznego urządzonego w celu upamiętnienia zdarzenia historycznego lub uczczenia osoby). Pamiętać należy, iż powyższe przestępstwo znieważenia nie jest tożsame z naruszeniem powagi miejsca. Zdecydowanie szersza ochrona przewidziana została w art. 9 ustawy z dnia 28 marca 1933 r. o grobach i cmentarzach wojennych ${ }^{88}$, w którym określono karę za m.in. zachowanie się na cmentarzu lub grobie wojennym w sposób nielicujący z powagą miejsca. Natomiast ochrony takiej nie ma w odniesieniu do cmentarzy komunalnych, ponieważ art. 262 $\S 1$ k.k., określający przestępstwo znieważenia zwłok, prochów ludzkich

87 Tekst jedn. Dz. U. z 2019 r. poz. 1950 z późn. zm.; dalej jako k.k.

${ }_{88}$ Tekst jedn. Dz. U. z 2018 r. poz. 2337. 
lub miejsc spoczynku zmarłego, może być niewystarczający, aby skutecznie zakazać odbycia zgromadzenia lub rozwiązać zgromadzenie już się odbywające na terenie cmentarza komunalnego i nielicujące z jego powagą. Miejsca te powinny podlegać ochronie w większym zakresie niż jest to przewidziane obecnie. Niekoniecznie chodzi przy tym o rozszerzenie odpowiedzialności karnej. Istotniejsze byłoby wprowadzenie przesłanki umożliwiającej zakazanie zorganizowania zgromadzenia oraz rozwiązanie odbywającego się zgromadzenia, jeśli nie licują one $\mathrm{z}$ powagą miejsca. Niewątpliwie tego typu ograniczenie wolności zgromadzeń wpisywałoby się w zakres konstytucyjnej przesłanki moralności publicznej i spełniałoby wymóg proporcjonalności, ponieważ nawet po dokonaniu stosownej zmiany prawa $\mathrm{w}$ ramach wolności zgromadzeń będzie można w dalszym ciągu głosić publicznie określone idee i poglądy, nawet te w odbiorze społecznym uznawane za kontrowersyjne (np. ze sfery seksualnej), w każdym innym miejscu publicznym, lecz nie w miejscu szczególnym, jakim jest teren cmentarza komunalnego. Postulowana zmiana prawa może skutecznie przeciwdziałać celowym prowokacjom mającym wywołać zainteresowanie medialne organizatorami lub uczestnikami zgromadzenia kosztem naruszenia powagi miejsc, które powinny podlegać szczególnej ochronie.

Zmiany prawa $\mathrm{w}$ omawianym zakresie są niewątpliwie możliwe i prawnie dopuszczalne. Nie stoją im na przeszkodzie ani ratyfikowane umowy międzynarodowe, ani Konstytucja. Ponadto wartość, jaką jest moralność publiczna, może być w większym zakresie stosowana przez ustawodawcę. Trzeba mieć jednak świadomość, iż ewentualne odnoszące się do tego zmiany wymagają woli politycznej, a tej - z uwagi na sporność może zabraknąć w szczególności w zakresie dotyczącym moralności publicznej w sferze seksualnej.

\section{ZAKOŃCZENIE}

Moralność publiczna stanowi przesłankę dopuszczalności ograniczenia wolności zgromadzeń zarówno na gruncie regulacji prawnomiędzynarodowych, jak i na gruncie polskiej Konstytucji. Niemniej jednak do ograniczenia tej wolności konieczne jest jeszcze obowiązywanie przepisów ustawowych określających szczegółowe przesłanki mieszczące się 
w moralności publicznej. Z przeprowadzonych badań wynika, iż niektóre obecnie obowiązujące regulacje ustawowe określają już w swej treści wartości, których ochrona może stanowić podstawę ograniczenia wolności zgromadzeń z uwagi na moralność publiczną. Ingerencja w wolność zgromadzeń może nastąpić zwłaszcza w przypadku naruszenia przepisów karnych chroniących wartości mieszczące się w moralności publicznej. Na gruncie obecnie obowiązującego ustawodawstwa może jednak dojść do ingerencji w omawianą wolność także bez odwołania się do naruszenia przepisów karnych, a więc w szczególności gdy cel lub odbycie zgromadzenia może naruszyć powagę lub charakter Pomnika Zagłady stanowiącego teren byłego hitlerowskiego obozu zagłady. Ochrona Pomników Zagłady mieści się bowiem w ochronie konstytucyjnej wartości moralności publicznej. Co więcej, za zasadne należy uznać zmiany ustawowe umożliwiające w większym zakresie stosowanie ograniczeń wolności zgromadzeń z uwagi na potrzebę ochrony moralności publicznej, w tym także w sferze seksualnej i w sferze obyczajności, lecz z uwzględnieniem utrwalonej już linii orzeczniczej ETPC i TS odnoszącej się do zakazu dyskryminacji mniejszości seksualnych. Stosowne zmiany w polskim ustawodawstwie są możliwe i potrzebne. W związku z postępującym w szczególności w Europie Zachodniej procesem liberalizacji moralności zarówno prywatnej, jak i publicznej, ich dokonanie może się jednak okazać niezwykle trudne.

\section{BIBLIOGRAFIA}

Banaszak, Bogusław. 2012. Konstytucja Rzeczypospolitej Polskiej. Komentarz. Warszawa: Legalis.

Czarnek, Przemysław. 2014. Wolność gospodarcza. Pierwszy filar społecznej gospodarki rynkowej. Lublin: Wydawnictwo KUL.

Florczak-Wątor, Monika. 2019. „Art. 57. Wolność zgromadzeń”. W: Konstytucja Rzeczypospolitej Polskiej. Komentarz, red. Piotr Tuleja. Warszawa: Wolters Kluwer.

Gajewski, Sebastian, Aleksander Jakubowski. 2017. Prawo o zgromadzeniach. Komentarz. Warszawa: Legalis. 
Gliszczyńska-Grabias, Aleksandra, Leszek Wiśniewski. 2012. „Art. 21 Wolność zgromadzeń". W: Międzynarodowy pakt praw obywatelskich (osobistych) i politycznych. Komentarz, red. Roman Wieruszewski. Warszawa: Wolters Kluwer. Kalisz, Anna. 2013. „Klauzula moralności (publicznej) w prawie polskim i europejskim jako przykład regulacyjnej, ochronnej oraz innowacyjnej funkcji prawa”. Principia LVII-LVIII: 191-213.

Mamak, Kamil. 2014. Prawo o zgromadzeniach. Komentarz. Warszawa: LexisNexis.

Nowicki, Marek A. 2013. Europejski Trybunat Praw Człowieka. Wybór orzeczeń. Warszawa: Lex.

Nowicki, Marek A. 2017. Wokół Konwencji Europejskiej. Komentarz do Europejskiej Konwencji Praw Człowieka. Warszawa: Lex.

Olejniczak-Szałowska, Ewa. 2020. „Bezpieczeństwo zgromadzeń publicznych i imprez masowych". W: Prawo administracyjne materialne, red. Zofia Duniewska, Barbara Jaworska-Dębska, Ewa Olejniczak-Szałowska, Małgorzata Stahl, Warszawa: Wolters Kluwer.

Podkowik, Jan. 2019. „Moralność publiczna jako przesłanka ograniczenia konstytucyjnych wolności i praw". Państwo i Prawo 8: 21-45.

Rzetecka-Gil, Agnieszka. 2019. Prawo o zgromadzeniach. Komentarz. Warszawa: Lex.

Skrzydło, Wiesław. 2013. Konstytucja Rzeczypospolitej Polskiej. Komentarz. Warszawa: Lex.

Sokolewicz, Wojciech, Krzysztof Wojtyczek. 2016. „Art. 57”. W: Konstytucja Rzeczypospolitej Polskiej. Komentarz. T. II, red. Leszek Garlicki, Marek Zubik. Warszawa: Wydawnictwo Sejmowe.

Suski, Paweł. 2014. Zgromadzenia i imprezy masowe. Warszawa: Lex.

Symonides, Janusz. 2005. „Ludność w prawie międzynarodowym”. W: Remigiusz Bierzanek, Janusz Symonides, Prawo międzynarodowe publiczne, 270-271. Warszawa: LexisNexis.

Szubiakowski, Marek. 2017. Administracyjnoprawna regulacja praw $i$ wolności obywatelskich. Warszawa: Wolters Kluwer.

Szustakiewicz, Przemysław. 2012. „Przesłanki i procedura zakazu zgromadzeń w świetle orzecznictwa sądów administracyjnych". Ius Novum 1: 159-167.

Wilk, Jakub. 2019. „Zgromadzenia”. W: Materialne prawo administracyjne, red. Marcin Miemiec. Warszawa: Wolter Kluwer.

Wróbel, Andrzej. 2010. „Artykuł 11”. W: Konwencja o Ochronie Praw Człowieka i Podstawowych Wolności. Komentarz do artykułów 1-18. T. I, red. Leszek Garlicki, Piotr Hofmański, Andrzej Wróbel. Warszawa: Legalis.

Zimmermann, Jan. 2018. Prawo administracyjne. Warszawa: Wolters Kluwer. 


\section{PUBLIC MORALITY \\ AS A PREMISE TO RESTRICT FREEDOM OF ASSEMBLY}

Abstract

Freedom of assembly may be also the subject of restrictions due to the need to protect public morality. Public morality is a premise for this freedom restricting under both international and national law. The research objective of the contribution is firstly, to show public morality as a premise of freedom of assembly restricting in the context of international and constitutional regulations and then, to show detailed statutory premises for interference with freedom of assembly included in the range of public morality. Although the possibilities for the freedom of assembly restricting due to the need to protect public morality are stipulated in the content of the ratified international agreements and also in the Constitution provisions, however statutory provisions being in force defining specific premises included in the range of public morality are also needed to restrict this freedom. Premises, which may constitute the legal basis for freedom of assembly restricting due to the need to protection of values included in public morality have been already specified in the content of some statutory regulations being in force. However, another statutory amendments allowing wider range of freedom of assembly restrictions due to the protection of public morality are required.

Key words: public morality; freedom of assembly; law on assemblies; restrictions on freedom; freedom of conscience and religion 